\title{
Editorial 9 (1)
}

\section{Jana Dlouhá}

Envigogika 9 (1) - Editorial/ Úvodník

Published /Publikováno 30. 5. 2014

DOI: $\underline{10.14712 / 18023061.445}$

Dear readers and other members of the Envigogika community,

We are pleased to inform you that new English issue is available online as of the end of May (along with the Czech versions of almost all texts) and we offer it to you for your perusal. Since the previous edition of Envigogika, our journal has undergone relatively substantial changes in order to raise its quality and academic recognition. Steps we have taken in this respect include:

- $\quad$ joining the CrossRef database. This means that all our articles are now indexed by the CrossRef database -all articles have their DOI;

- $\quad$ improving referencing. Joining the CrossRef obliges us to use DOI links also for all references in all articles which have $\mathrm{DOI}$ - by the end of the summer we hope to upgrade references and other details in all pdf versions (also retrospectively);

- $\quad$ joining Open Archives Initiative;

- joining the WorldCat OCLC database;

- joining Sherpa/Romeo;

- $\quad$ application for inclusion to the OAlster database;

- improving our publication policy and ethical code of conduct;

- broadening the scope of journal so that now it might be concerned with other sustainability oriented issues: including psychological and behavioural themes, sustainable (regional) development issues and analyses of related (social) transformations, reflections of the social role of science, and of course discussions on whole range of prerequisites and barriers for quality EE and ESD on different education levels;

- $\quad$ based on these steps we have also applied for being embedded in the SCOPUS database and DOAJ directory;

- $\quad$ last but not least we have extended our supporting international professional community inviting new editorial board members who are warmly welcome to share their ideas and views with us and to support the journal's editing policy.

We have a small editorial team, and so all these activities have been quite demanding. However now we are happy to offer you the first issue of this year in which you can find following: a text by Jan Činčera and his colleagues "Organic food is fertilised at night": Why people (do not) buy environmentally friendly products in which the authors analyze barriers for environmentally friendly consumer behaviour in relation to consumers' personal history. Lubomír Hanel and Jana Hanelová explore parental care of the genus Elasmucha and outline principles of direct observation of the environment and practical scientific enquiry outside the classroom which they consider to be fundamental to an understanding of the nature of science for which they show its application in education. In relation to the document Peoples' Sustainability Treaty on Higher Education Towards Sustainable Development, the last article from the reviewed column: Higher education for 
sustainability - a change of education genre? demonstrates the main changes currently in progress in higher education curricula, both based on theoretical considerations and providing practical examples of innovations in HE teaching in the context of CR universities.

For Inspiration, we recommend you the text by Beáta Tisucká: The intertwinedness of forest and cultural landscapes in the context of cultural ecology where she discusses how nature is reflected in the social discourse and aesthetically interpreted so that it can be "read as a text". Petr Mikšiček has a close relationship with the Ore Mountain region and writes about its landscape full of cultural footprints left by former inhabitants, the destruction of which also erases our memory (Discovery of a supposed extinct settlement species made at Königsmühle in the Ore Mountains). In her interview with Daniella Tilbury, Majda Naji learns more about the UNESCO Monitoring and Evaluation Expert Group (MEEG) working in the framework of the United Nations Decade in Education for Sustainable Development which reflects the results of and prepares follow up to the Decade.

We would also like to draw your attention to the latest news and announcements: first of all, we are supporting GUNI in its effort to distribute its latest report on higher education in the World. Secondly, and highly relevant for Envigogika, we announce a new call for papers for a thematic issue which will be focused on competences in environmental education and education for sustainable development and will be published as a follow-up to the international COPERNICUS Alliance conference to be held in Prague in the beginning of October ${ }^{1}$. We hope to meet some of you there soon!

We wish you enjoyable reading, and sunny summer wherever you are

On behalf of the Envigogika editorial team

Jana and Jiří Dlouhý

\footnotetext{
${ }^{1}$ A further issue which will be comprised of regional sustainability case studies (working title "Social learning processes for regional sustainable development", see here) is still under preparation. Shorter examples of regional development highlighting the roles of its actors are welcome to be included in non-research sections or into the related database.
} 